\title{
A Study on Digital Ability Change after the Smart Worker Education of the Prime-Aged Learner
}

\author{
Mariah Park and Tea In Han
}

\begin{abstract}
Lifelong learning organization have been accomplishing computerization education for prime-aged learners in Korea. In early days, it started from computer literacy education, and it carried over information utilization, internet utilization, smart-phone utilization, video production, and SNS utilization.

This study aimed to the ability improvement for information utilization change of the prime-aged learners after smart worker curriculum learning, the education program carry out smart worker education differentiated from the existing computerization education by prime-aged learners who faced to the smart working era.

Therefore, this study chose prime-aged educational program in progress throughout one of the ${ }^{1}$ lifelong learning organization of the Gwangju area in Korea. This curriculum was designed by the smart worker ability subjects, it included ability for documentation, smart ability for apparatus utilization, ability for collaborative work, information management ability for cloud utilization that was a basic ability of smart working.

It was performed from the questionnaire survey to the statistical analysis about the factor of ability for documentation, smart ability for apparatus utilization, ability for collaborative work, information management capability for the learners who learned this class.

As a result, ability improvement for information utilization appeared significantly in all factors of cloud utilization, smart apparatus utilization, documentation, collaborative work, and information management after learners completed education program of smart worker curriculum. Based on this research result, study about the relation between improvement of the ability for information utilization and change of smart working style will have to be progressed continuously in the future.
\end{abstract}

Index Terms-Cloud working, lifelong education, prime aged person, smart work.

\section{INTRODUCTION}

\section{A. Research Background}

The concept of the lifelong learning means education to be provided throughout the life [1]. There learning should be performed and managed continuously. Nowadays information and communication technology changed rapidly, and old aged and prime aged people could not keep the pace with the trend.

It could be called life literacy that people cannot understand or utilize computer, internet and smart apparatus

Manuscript received August 1, 2018, revised September 7, 2018.

The authors are with the Dept. of e-Learning Graduate School, Korea National Open University, Seoul, Korea (correspondence author: Tea In Han; e-mail: mra1028@knou.ac.kr). conveniently.

According to the IT environment change, utilization of smart apparatus should be essential in cloud communication environment for work [2]. But in general such a change complicates an old person. It led the prime aged person to escape from an existing working condition because it is not easy to adapt itself.

It was performed as basic education from the computer basics to the internet utilization, smart phone education and the video manipulation education throughout the life in Korea. It has been progressed and established a curriculum differentiated from the existing computerization education to the documentation skill that utilized a cloud and the web office program, smart phone application, smart ability for apparatus utilization.

This study progressed with the one of the lifelong education organization in Gwangju area in Korea, they educated smart worker program for prime aged person. As for the purpose of the learning program, a learner can carry out a smart work in their work environment after a class.

\section{B. Goal}

It may be said that the information utilization ability of the learner is lower than a young man. For prime aged person, there were not curriculum related to computer, therefore they cannot but learn in real life, it means that they can edit or revise document which other person produce, and they can search the information inefficiently because they are not used to collaborative work in web.

The purpose of the smart work class for prime aged person is improving the digital ability after class, and they apply it to the real smart work in job. Therefore this study is going to confirm the class that appeared in this way whether smart work application change to the learner later.

It include the ability of digital utilization that improved by a change of the ability for smart apparatus utilization, the ability for web office utilization with cloud base and utilization skill of the smart working tool after class completion for many years.

\section{RELATED WORK}

\section{A. Smart Worker}

Work process style should be changed according to the cloud service and smart apparatus utilizing in work. When worker use cloud service, from the storing the data in USB or HDD in PC to creating, manipulating, storing and communicating with collaborative workers in same space in web [3], it means that they share a saved document together and they can utilize it for collaborative work. 
As the handling of work style that worker utilize a web office program, and an individual handled becomes able to carry out the collaborative operation change [1]. The smart worker is a person raising business efficiency using the apparatus which is appropriate when it is necessary creatively [4].

TABLE I: DEFINITION OF SMART WORK

\begin{tabular}{|c|c|}
\hline author & definition \\
\hline $\begin{array}{c}\text { National } \\
\text { Information } \\
\text { Society } \\
\text { Agency [2] }\end{array}$ & $\begin{array}{l}\text { It is the ability that not only makes a thought } \\
\text { differentiated in a knowledge information-oriented } \\
\text { society, and does a thing creatively, but also can } \\
\text { start result, it define it as the networking with } \\
\text { anyone using ICT in time, the place when I can } \\
\text { work together on a network }\end{array}$ \\
\hline $\begin{array}{l}\text { Kyu-Sung } \\
\text { Noh, } \\
\text { Kwui-Gon } \\
\text { Kim, } \\
\text { Jong-Bong } \\
\text { Byun [5] }\end{array}$ & $\begin{array}{l}\text { The information ability is important to an adult } \\
\text { learner, too, but a variety of smart working tools and } \\
\text { the learning for the skill to use for real works are } \\
\text { necessary, and practice of the utilization is } \\
\text { necessary. And the core ability model of the smart } \\
\text { worker is sorted with an originality innovation } \\
\text { ability, a social ability, a digital ability. }\end{array}$ \\
\hline $\begin{array}{c}\text { Itsuhiro } \\
\text { Okada [6] }\end{array}$ & $\begin{array}{l}\text { The processing capacity of the work of the smart } \\
\text { worker utilizes a free high-performance tool such as } \\
\text { Google assuming the digitization of the thing. }\end{array}$ \\
\hline $\begin{array}{l}\text { Eong-beom } \\
\text { Gang, } \\
\text { Su-yong } \\
\text { Jeong [4] }\end{array}$ & $\begin{array}{l}\text { As it means a person raising the efficiency of the } \\
\text { business using an appropriate apparatus creatively } \\
\text { when it is necessary, it does not mean only what use } \\
\text { the from beginning to end smart apparatus early } \\
\text { simply for } 24 \text { hours, and find out necessary } \\
\text { information promptly }\end{array}$ \\
\hline
\end{tabular}

\section{B. Ability of Smart Worker}

The smart work ability can be identified with three core ability of an originality innovation ability, a social ability, a digital ability for the smart worker in a precedent study [7].

TABLE II: DIGITAL ABILITY FOR SMART WORKER

\begin{tabular}{|c|c|}
\hline Ability & Tool to use \\
\hline $\begin{array}{l}\text { Information Mngt. } \\
\text { ability }\end{array}$ & $\begin{array}{l}\text { Google drive, Google photo, One drive, N } \\
\text { drive, Dropbox, Amazon, Apple i cloud, } \\
\text { Flicker, IDC cloud, YouTube }\end{array}$ \\
\hline $\begin{array}{l}\text { Document Making } \\
\text { Ability }\end{array}$ & $\begin{array}{l}\text { PC: Hangul, MS word, Excel, PowerPoint, } \\
\text { keynote, Office program: Office } 365 \text {, Naver } \\
\text { office(word, cell, slide, form) } \\
\text { Google: Document, Presentation, } \\
\text { Spreadsheet, Questionnaire } \\
\text { Ever note, OK mindmap }\end{array}$ \\
\hline $\begin{array}{l}\text { Information } \\
\text { Collection Ability }\end{array}$ & $\begin{array}{l}\text { PC: Internet Explorer, Chrome, Fire Fox, } \\
\text { Mona Lisa } \\
\text { App: Chrom app, Google Search, Daum app, } \\
\text { Naver app } \\
\text { Site: Google, Daum, Naver, Bing, Yahoo }\end{array}$ \\
\hline $\begin{array}{l}\text { Information } \\
\text { Sharing Ability }\end{array}$ & $\begin{array}{l}\text { e-Mail, Calender, Work list, Wikipedia, } \\
\text { Namu wiki, Cloud sourcing, Open source, } \\
\text { Naver intelligence }\end{array}$ \\
\hline $\begin{array}{l}\text { Communication } \\
\text { Ability }\end{array}$ & $\begin{array}{l}\text { Google hangout, Meet, Messenger, Kakao } \\
\text { talk }\end{array}$ \\
\hline $\begin{array}{l}\text { Social Network or } \\
\text { Community } \\
\text { Ability }\end{array}$ & $\begin{array}{l}\text { Linked in, Linknow, Goole Plus, Blog, } \\
\text { Facebook, Twitter, Kakao story, Naver band, } \\
\text { Line, Jandi }\end{array}$ \\
\hline $\begin{array}{l}\text { Apparatus } \\
\text { Utilization Ability }\end{array}$ & $\begin{array}{l}\text { PC, Notebook, Mobile phone, Smart phone, } \\
\text { Tablet PC, PDA, NAS, USB, HDD }\end{array}$ \\
\hline
\end{tabular}

\section{Class Structure of Digital Ability for Smart Worker}

In smart worker class, it focus on four core abilities for digital ability of the smart ability, and the class teaches the IT tools like <Table III> for each digital ability. This study applied digital ability of three kinds of abilities, and restructured it from the original reference [8] <Table II $>$ to $<$ Table III $>$, and questionnaire item and the variable name for four factors are following <Table III> [9].

TABLE III: SURVEY ITEM AND VARIABLE NAME

\begin{tabular}{cl}
\hline \hline ability & \multicolumn{1}{c}{ survey item and variable name } \\
$\begin{array}{c}\text { Cloud } \\
\text { Utilization }\end{array}$ & $\begin{array}{l}\text { drive data storing(C1), photo storing(C2), } \\
\text { document sharing(C3) }\end{array}$ \\
\hline $\begin{array}{c}\text { Apparatus } \\
\text { Utilization }\end{array}$ & $\begin{array}{l}\text { mobile drive(A1), mobile photo utilizing(A2), } \\
\text { mobile spreadsheet(A3) }\end{array}$ \\
\hline $\begin{array}{c}\text { Document } \\
\text { Making }\end{array}$ & $\begin{array}{l}\text { document work(D1), PPT(D2), } \\
\text { spreadsheet(D3), note(D4), } \\
\text { mind map(D5) }\end{array}$ \\
\hline $\begin{array}{c}\text { Information } \\
\text { Management. }\end{array}$ & $\begin{array}{l}\text { file transmission(I1), web PPT(I2), } \\
\text { survey management(I3), document share(I4) }\end{array}$ \\
\hline \hline
\end{tabular}

\section{RESEARCH DESIGN}

\section{A. Research Hypothesis}

The learners after finishing smart class

1) Improve cloud utilization ability and use it to the real work,

2) Improve apparatus utilization ability and use it to the real work,

3) Improve document making ability and use it to the real work,

4) Improve information management ability and use it to the real work.

\section{B. Research Method}

It applies to nineteen prime aged learners who participated in smart worker learning program named "I am the smart worker form today” during From March 2017 until June 2018 around Gwangju area in Korea [10].

It applied in 44 responders by the pre and post two questionnaire survey to check the ability change, by the primary questionnaire to ask the beforehand knowledge for computer utilization, internet utilization and smart phone utilization. By the second survey, to ask the cloud utilization ability, the apparatus utilization ability, the document making ability and the information management ability [11].

\section{RESUlT OF RESEARCH}

\section{A. Survey Item Reliability Analysis}

The <Table IV> shows the questionnaire item reliability analysis result. As for the analysis, result became very clear with what meant it statistically.

\section{B. Analysis of Digital Ability before the Class}

\section{1) Smartphone utilization ability}

Among 44 responder, it showed internet search feature utilization $100 \%$, photograph video photography $88.6 \%$, chat service $81.8 \%$, transportation service $56.8 \%$, email $50.0 \%$, finance $47.7 \%$, preservation service and SNS $38.6 \%$, online 
shopping $36.4 \%$, online learning $31.8 \%$, online game $11.4 \%$, mobile fax $9.1 \%$, and use of mobile hotspot $6.8 \%$. Responder were smart phone users, and they could select multiple choice.

They showed relatively high utilization by smart phone application utilization $79.5 \%$, transmitted document management utilization $77.3 \%$, transmitted photograph utilization $79.5 \%$, it means prime aged learner was good at the use of the basic function of the smart phone, but they did not use mobile fax, mobile tethering function with the degree of difficulty.

TABLE IV : SURVEY ITEM RELIABILITY ANALYSIS

\begin{tabular}{|c|c|c|c|c|c|c|}
\hline \multirow{2}{*}{ Ability } & \multirow{2}{*}{$\begin{array}{l}\mathrm{n} \text { of } \\
\text { item }\end{array}$} & \multirow{2}{*}{$\begin{array}{c}\text { Cronbach } \\
\text { alpha }\end{array}$} & \multicolumn{4}{|c|}{ statistic of variable } \\
\hline & & & variable & mean & sd & $\mathrm{n}$ \\
\hline \multirow{3}{*}{$\begin{array}{l}\text { Cloud } \\
\text { Utilization }\end{array}$} & \multirow{3}{*}{3} & \multirow{3}{*}{.864} & $\mathrm{C} 1$ & 4.23 & .831 & 44 \\
\hline & & & $\mathrm{C} 2$ & 4.45 & .761 & 44 \\
\hline & & & C3 & 3.93 & 1.021 & 44 \\
\hline \multirow{3}{*}{$\begin{array}{l}\text { Apparatus } \\
\text { Utilization }\end{array}$} & \multirow{3}{*}{3} & \multirow{3}{*}{.822} & A1 & 4.20 & .851 & 44 \\
\hline & & & A2 & 4.36 & .750 & 44 \\
\hline & & & A3 & 4.30 & .701 & 44 \\
\hline \multirow{5}{*}{$\begin{array}{l}\text { Document } \\
\text { Making }\end{array}$} & \multirow{5}{*}{5} & \multirow{5}{*}{.837} & D1 & 4.18 & .870 & 44 \\
\hline & & & D2 & 4.07 & .759 & 44 \\
\hline & & & D3 & 4.14 & .765 & 44 \\
\hline & & & D4 & 4.16 & .834 & 44 \\
\hline & & & D5 & 4.09 & .830 & 44 \\
\hline \multirow{4}{*}{$\begin{array}{l}\text { Information } \\
\text { Management. }\end{array}$} & \multirow{4}{*}{4} & \multirow{4}{*}{.864} & I1 & 3.73 & 1.065 & 44 \\
\hline & & & $\mathrm{I} 2$ & 4.02 & .821 & 44 \\
\hline & & & $\mathrm{I} 3$ & 4.16 & .805 & 44 \\
\hline & & & I4 & 3.93 & .998 & 44 \\
\hline
\end{tabular}

\section{2) Computer and internet utilization ability}

As for the computer utilization, document work and internet banking $59.1 \%$, information retrieval $54.5 \%$, online shopping $50.0 \%$, music, movie, TV watch $45.5 \%$, SNS $29.5 \%$, chatting $29.5 \%$, online learning $25.0 \%$, online game $18.2 \%$ was showed. For the internet browser, Explorer $81.8 \%$, Chrome $18.2 \%$ was showed. For web site, Daum 43.2\%, Naver $45.5 \%$, Google $11.4 \%$ wad showed. When other web browser was needed, give up $84.1 \%$, search and use $15.9 \%$ was showed.

\section{3) Recognition for smart worker learning program}

1) Have heard smart worker class.

It showed Chrome browsers $84.1 \%$, Google questionnaire $70.5 \%$, G-mail $68.2 \%$, Google photo $65.9 \%$, Google calendar $38.6 \%$, Google drive $63.6 \%$, Ever note $61.4 \%$, Google spreadsheet $59.1 \%$, Google presentation $45.5 \%$, Google document and Scrap 43.2 \%, OK Mindmap 40.9\%, N drive $25.0 \%$, Drop box $15.9 \%$, Hang out $13.6 \%$, Office $36511.4 \%$. As for the beforehand knowledge for the subject between learners, a deviation greatly emerged

2) Have used it more than once anout smart worker class

It showed Google drive 40.9\%, Google photo and Google calendar $34.1 \%$, Chrom browsers and G-mail 29.5\%, Google spreadsheet $18.2 \%$, Evernote $20.5 \%$, Google questionnaire $15.9 \%, \mathrm{~N}$ drive $11.4 \%$, OK Mindmap 9.1\%, Google document $6.8 \%$, Google presentation, office 365 and scrap 2.3\%, Hang out and Dropbox 0\%.

\section{Analysis of Digital Ability after the Class}

\section{1) Cloud utilization ability}

The cloud utilization ability is comprised of drive data storing, photo storing and document sharing on the cloud, and the reply for cloud utilization ability is showed <Table V> after class. And the analysis of variance for the cloud utilization ability by ability for use of PC is the same as $<$ Table VI>.

This table showed the change of ability after class by the PC utilization before class. According the statistical analysis, the change of cloud utilization ability after class between two groups of PC utilization ability became clear with different one.

TABLE V: RESULT FOR CLOUD UTILIZATION ABILITY

\begin{tabular}{lccccc}
\hline \hline variables / point & 5 & 4 & 3 & 2 & 1 \\
\hline drive data storing(C1) & $47.7 \%$ & $27.3 \%$ & $25.0 \%$ & $0 \%$ & $0 \%$ \\
\hline photo storing(C2) & $61.4 \%$ & $22.7 \%$ & $15.9 \%$ & $0 \%$ & $0 \%$ \\
\hline document sharing(C3) & $40.9 \%$ & $18.2 \%$ & $34.1 \%$ & $6.8 \%$ & $0 \%$ \\
\hline \hline
\end{tabular}

TABLE VI: ANOVA RESUlt OF CLOUD UtILIZATION ABILITY BY PC

\begin{tabular}{|c|c|c|c|c|c|c|}
\hline \multicolumn{7}{|c|}{ UTILIZATION } \\
\hline & ree & $\begin{array}{c}\text { sum of } \\
\text { squares }\end{array}$ & $\mathrm{df}$ & $\begin{array}{l}\text { mean } \\
\text { square }\end{array}$ & F-value & p-value \\
\hline \multirow{3}{*}{$\mathrm{C} 1$} & Treatments & 8.771 & 2 & 4.386 & $8.580^{* * *}$ & .001 \\
\hline & Error & 20.956 & 41 & .511 & & \\
\hline & Total & 29.727 & 43 & & & \\
\hline \multirow{3}{*}{$\mathrm{C} 2$} & Treatments & 3.445 & 2 & 1.722 & $3.290^{*}$ & .047 \\
\hline & Error & 21.464 & 41 & .524 & & \\
\hline & Total & 24.909 & 43 & & & \\
\hline \multirow{3}{*}{$\mathrm{C} 3$} & Treatments & 10.500 & 2 & 5.250 & $6.276^{* *}$ & .004 \\
\hline & Error & 34.295 & 41 & .836 & & \\
\hline & Total & 44.795 & 43 & & & \\
\hline
\end{tabular}

The analysis of variance for the cloud utilization ability by ability for use of mobile phone was the same as <table VII >.

This table showed the change of ability after class by the mobile phone utilization before class. According the statistical analysis, the change of cloud utilization ability after class between two groups of mobile phone utilization ability became clear with different one.

TABLE VII: ANOVA RESULT OF APPARATUS UTILIZATION ABILITY BY MOBILE PHONE UTILIZATION

\begin{tabular}{rlrrrrr}
\hline \multicolumn{2}{c}{ source } & $\begin{array}{c}\text { sum of } \\
\text { squares }\end{array}$ & df & $\begin{array}{c}\text { mean } \\
\text { square }\end{array}$ & F-value & p-value \\
\hline \multirow{2}{*}{ C1 } & Treatments & 4.690 & 2 & 2.345 & $3.840^{*}$ & .030 \\
& Error & 25.038 & 41 & .611 & & \\
& Total & 29.727 & 43 & & & \\
\hline \multirow{2}{*}{$\mathrm{C} 2$} & Treatments & 5.309 & 2 & 2.655 & $5.553^{* *}$ & .007 \\
& Error & 19.600 & 41 & .478 & & \\
& Total & 24.909 & 43 & & & \\
\hline \multirow{2}{*}{$\mathrm{C} 3$} & Treatments & 13.918 & 2 & 6.959 & $9.240^{* * *}$ & .000 \\
& Error & 30.878 & 41 & .753 & & \\
& Total & 44.795 & 43 & & & \\
\hline$p<0.05, * * p<0.01, * * * p<0.001$ & & & & &
\end{tabular}

2) Apparatus utilization ability 
It is comprised of mobile drive, mobile photo and mobile spreadsheet utilization on the cloud, and the reply for apparatus utilization ability is showed <Table VIII> after class.

And the analysis of variance for this factor by ability for use of PC is the same as <Table IX>.

This table showed the change of ability after class by the PC utilization before class. According the statistical analysis, the change of apparatus utilization ability after class between two groups of PC utilization ability became clear with different one. But the table showed that difference between two groups was not clear on mobile photo utilization ability.

TABLE VIII: APPARATUS UTILIZATION ABILITY

\begin{tabular}{lccccc}
\hline \hline \multicolumn{1}{c}{ variables / point } & 5 & 4 & 3 & 2 & 1 \\
\hline mobile drive (A1) & $45.5 \%$ & $31.8 \%$ & $20.5 \%$ & $2.3 \%$ & $0 \%$ \\
\hline mobile photo utilizing (A2) & $52.3 \%$ & $31.8 \%$ & $15.9 \%$ & $0 \%$ & $0 \%$ \\
\hline mobile spreadsheet (A3) & $43.2 \%$ & $43.2 \%$ & $13.6 \%$ & $0 \%$ & $0 \%$ \\
\hline \hline
\end{tabular}

TABLE IX: ANOVA RESULT APPARATUS UTILIZATION ABILITY BY PC UTILIZATION

\begin{tabular}{rlrrrrr}
\hline \multicolumn{2}{c}{ source } & $\begin{array}{c}\text { sum of } \\
\text { squares }\end{array}$ & df & $\begin{array}{c}\text { mean } \\
\text { square }\end{array}$ & F-value & p-value \\
\hline \multirow{4}{*}{ A1 } & Treatments & 9.890 & 2 & 4.945 & $9.533^{* * *}$ & .000 \\
& Error & 21.269 & 41 & .519 & & \\
& Total & 31.159 & 43 & & & \\
\hline \multirow{4}{*}{$\mathrm{A} 2$} & Treatments & 3.266 & 2 & 1.633 & 3.201 & .051 \\
& Error & 20.916 & 41 & .510 & & \\
& Total & 24.182 & 43 & & & \\
\hline \multirow{2}{*}{$\mathrm{A} 3$} & Treatments & 4.628 & 2 & 2.314 & $5.740^{* * *}$ & .006 \\
& Error & 16.531 & 41 & .403 & & \\
& Total & 21.159 & 43 & & & \\
\hline$* p<0.05, * * p<0.01, * * * p<0.001$ & & & &
\end{tabular}

The analysis of variance for the apparatus utilization ability by ability for use of mobile phone was the same as $\langle$ Table X>.

This table showed the change of ability after class by the mobile phone utilization before class.

According the statistical analysis, the change of apparatus utilization ability after class between two groups of mobile phone utilization ability became clear with different one. But table showed week difference between two groups on mobile drive and mobile photo ability variables.

TABLE X: ANOVA RESULT OF APPARATUS UTILIZATION ABILITY BY MobiLE PHONE UTILIZATION

\begin{tabular}{rlrrrrr}
\multicolumn{6}{c}{ MOBILE PHONE UTILIZATION } \\
\hline \multirow{2}{*}{ source } & $\begin{array}{c}\text { sum of } \\
\text { squares }\end{array}$ & df & $\begin{array}{c}\text { mean } \\
\text { square }\end{array}$ & F-value & p-value \\
\hline \multirow{2}{*}{ A1 } & Treatments & 6.059 & 2 & 3.030 & $4.949^{*}$ & .012 \\
& Error & 25.100 & 41 & .612 & & \\
& Total & 31.159 & 43 & & & \\
\hline \multirow{2}{*}{ A2 } & Treatments & 4.700 & 2 & 2.350 & $4.945^{*}$ & .012 \\
& Error & 19.482 & 41 & .475 & & \\
& Total & 24.182 & 43 & & & \\
\hline \multirow{4}{*}{ A3 } & Treatments & 8.059 & 2 & 4.030 & $12.612^{* * *}$ & .000 \\
& Error & 13.100 & 41 & .320 & & \\
& Total & 21.159 & 43 & & & \\
\hline *p<0.05, $* * \mathrm{p}<0.01, * * * \mathrm{p}<0.001$ & & & &
\end{tabular}

\section{3) Document making ability}

Document making ability is comprised of document work, presentation, spreadsheet, Evernote and Ok mindmap on the cloud, and the reply for this factor is showed <Table XI> after class. And the analysis of variance for this factor by ability for use of PC is the same as <Table XII >

This table showed the change of ability after class by the PC utilization before class. According the statistical analysis, the change of document making utilization ability after class between two groups of PC utilization ability became clear with different one.

But the <Table XI> showed that difference between two groups was not clear with the mobile photo utilization ability variables.

TABLE XI: DOCUMENT MAKING ABILITY

\begin{tabular}{lccccc}
\hline \hline \multicolumn{1}{c}{ variables / point } & 5 & 4 & 3 & 2 & 1 \\
\hline document work(D1) & $45.5 \%$ & $29.5 \%$ & $22.7 \%$ & $2.3 \%$ & $0 \%$ \\
\hline presentation(D2) & $31.8 \%$ & $43.2 \%$ & $25.0 \%$ & $0 \%$ & $0 \%$ \\
\hline spreadsheet(D3) & $36.4 \%$ & $40.9 \%$ & $22.7 \%$ & $0 \%$ & $0 \%$ \\
\hline Evernote (D4) & $40.9 \%$ & $36.4 \%$ & $20.5 \%$ & $2.3 \%$ & $0 \%$ \\
\hline Ok Mindmap (D5) & $38.6 \%$ & $31.8 \%$ & $29.5 \%$ & $0 \%$ & $0 \%$ \\
\hline \hline
\end{tabular}

TABLE XII: ANOVA RESULT OF DOCUMENT MAKING ABILITY BY PC

\begin{tabular}{|c|c|c|c|c|c|c|}
\hline \multicolumn{2}{|c|}{ source } & $\begin{array}{l}\text { sum of } \\
\text { squares }\end{array}$ & $\mathrm{df}$ & $\begin{array}{c}\text { mean } \\
\text { square }\end{array}$ & F-value & $\mathrm{p}$-value \\
\hline \multirow{3}{*}{ D1 } & Treatments & 10.604 & 2 & 5.302 & $9.908^{* * * *}$ & .000 \\
\hline & Error & 21.941 & 41 & .535 & & \\
\hline & Total & 32.545 & 43 & & & \\
\hline \multirow{3}{*}{ D2 } & Treatments & 5.871 & 2 & 2.936 & $6.360^{* * *}$ & .004 \\
\hline & Error & 18.924 & 41 & .462 & & \\
\hline & Total & 24.795 & 43 & & & \\
\hline \multirow{3}{*}{ D3 } & Treatments & 3.546 & 2 & 1.773 & $3.360^{*}$ & 0.45 \\
\hline & Error & 21.635 & 41 & .528 & & \\
\hline & Total & 25.182 & 43 & & & \\
\hline \multirow{3}{*}{ D4 } & Treatments & 8.986 & 2 & 4.493 & $8.814^{* * * *}$ & .001 \\
\hline & Error & 20.900 & 41 & .510 & & \\
\hline & Total & 29.886 & 43 & & & \\
\hline \multirow{3}{*}{ D5 } & Treatments & 5.630 & 2 & 2.815 & $4.807^{*}$ & .013 \\
\hline & Error & 24.007 & 41 & .586 & & \\
\hline & Total & 29.636 & 43 & & & \\
\hline
\end{tabular}

The analysis of variance for the document making utilization ability by ability for use of mobile phone was the same as <Table XIII>.

This table showed the change of ability after class by the mobile phone utilization before class. According the statistical analysis, the change of apparatus utilization ability after class between two groups of mobile phone utilization ability became clear with different one.

TABLE XIII: ANOVA RESUlt OF DOCUMENT MAKING ABILITY By MobILE PHONE UTILIZATION

\begin{tabular}{rlrrrrr}
\hline \multicolumn{2}{c}{ source } & $\begin{array}{c}\text { sum of } \\
\text { squares }\end{array}$ & df & \multicolumn{1}{c}{$\begin{array}{c}\text { mean } \\
\text { square }\end{array}$} & F-value & p-value \\
\hline \multirow{2}{*}{ D1 } & Treatments & 7.897 & 2 & 3.948 & $6.568^{* * *}$ & .003 \\
& Error & 24.649 & 41 & .601 & & \\
& Total & 32.545 & 43 & & & \\
\hline \multirow{2}{*}{ D2 } & Treatments & 5.434 & 2 & 2.717 & $5.754^{* * *}$ & .006 \\
& Error & 19.361 & 41 & .472 & & \\
& Total & 24.795 & 43 & & & \\
\hline \multirow{2}{*}{ D3 } & Treatments & 7.032 & 2 & 3.516 & $7.942^{* * *}$ & .001 \\
& Error & 18.150 & 41 & .443 & &
\end{tabular}




\begin{tabular}{rlrrrrr} 
& Total & 25.182 & 43 & & & \\
\hline \multirow{4}{*}{ D4 } & Treatments & 2.525 & 2 & 1.263 & 1.892 & .164 \\
& Error & 27.361 & 41 & .667 & & \\
& Total & 29.886 & 43 & & & \\
\hline \multirow{2}{*}{ D5 } & Treatments & 2.921 & 2 & 1.461 & 2.241 & .119 \\
& Error & 26.715 & 41 & .652 & & \\
& Total & 29.636 & 43 & & & \\
\hline &
\end{tabular}

\section{4) Information management ability}

Information management ability is comprised of file transmission, web presentation, survey management and document sharing abilities on the cloud, and the reply for information management ability is showed 〈Table XIV> after class. And the analysis of variance for this factor by ability for use of $\mathrm{PC}$ is the same as $\langle$ Table $\mathrm{XV}\rangle$.

TABLE XIVII: INFORMATION MANAGEMENT ABILITY

\begin{tabular}{lccccc}
\hline \hline \multicolumn{1}{c}{ variables / point } & 5 & 4 & 3 & 2 & 1 \\
\hline file transmission (I1) & $38.6 \%$ & $22.7 \%$ & $31.8 \%$ & $6.8 \%$ & $0 \%$ \\
\hline web presentation(I2) & $31.8 \%$ & $40.9 \%$ & $25.0 \%$ & $2.3 \%$ & $0 \%$ \\
\hline survey management (I3) & $38.6 \%$ & $40.9 \%$ & $25.0 \%$ & $2.3 \%$ & $0 \%$ \\
\hline document share (I4) & $31.8 \%$ & $20.5 \%$ & $38.6 \%$ & $6.8 \%$ & $2.3 \%$ \\
\hline \hline
\end{tabular}

TABLE XVIII: ANOVA RESULT OF INFORMATION MANAGEMENT ABILITY BY PC UTILIZATION

\begin{tabular}{|c|c|c|c|c|c|c|}
\hline \multicolumn{2}{|c|}{ source } & $\begin{array}{l}\text { sum of } \\
\text { squares }\end{array}$ & df & $\begin{array}{c}\text { mean } \\
\text { square }\end{array}$ & F-value & $\mathrm{p}$-value \\
\hline \multirow{3}{*}{ I1 } & Treatments & 18.887 & 2 & 9.444 & $16.195^{\text {**k }}$ & .000 \\
\hline & Error & 23.908 & 41 & .583 & & \\
\hline & Total & 42.795 & 43 & & & \\
\hline \multirow{3}{*}{$\mathrm{I} 2$} & Treatments & 5.559 & 2 & 2.779 & $4.866^{\text {** }}$ & .013 \\
\hline & Error & 23.418 & 41 & .571 & & \\
\hline & Total & 28.977 & 43 & & & \\
\hline \multirow{3}{*}{ I3 } & Treatments & 5.839 & 2 & 2.920 & $5.429^{* * *}$ & .008 \\
\hline & Error & 22.047 & 41 & .571 & & \\
\hline & Total & 27.886 & 43 & & & \\
\hline \multirow{3}{*}{ I4 } & Treatments & 11.779 & 2 & 5.890 & $6.536^{* *}$ & .003 \\
\hline & Error & 36.948 & 41 & .901 & & \\
\hline & Total & 48.727 & 43 & & & \\
\hline
\end{tabular}

TABLE XVI: ANOVA RESULT OF INFORMATION MANAGEMENT ABILITY

\begin{tabular}{|c|c|c|c|c|c|c|}
\hline \multicolumn{7}{|c|}{ BY MOBILE PHONE UTILIZATION ABILITY } \\
\hline \multicolumn{2}{|c|}{ source } & $\begin{array}{l}\text { sum of } \\
\text { squares }\end{array}$ & df & $\begin{array}{c}\text { mean } \\
\text { square }\end{array}$ & F-value & p-value \\
\hline \multirow{3}{*}{ I1 } & Treatments & 16.980 & 2 & 8.490 & $13.484^{* * *}$ & .000 \\
\hline & Error & 25.815 & 41 & .630 & & \\
\hline & Total & 42.795 & 43 & & & \\
\hline \multirow{3}{*}{$\mathrm{I} 2$} & Treatments & 7.366 & 2 & 3.683 & $6.987^{* *}$ & .002 \\
\hline & Error & 21.611 & 41 & .527 & & \\
\hline & Total & 28.977 & 43 & & & \\
\hline \multirow{3}{*}{ I3 } & Treatments & 9.571 & 2 & 4.786 & $10.713^{* * *}$ & .000 \\
\hline & Error & 18.315 & 41 & .447 & & \\
\hline & Total & 27.886 & 43 & & & \\
\hline \multirow{3}{*}{ I4 } & Treatments & 15.283 & 2 & 7.641 & $9.368^{* * * *}$ & .000 \\
\hline & Error & 33.444 & 41 & .816 & & \\
\hline & Total & 48.727 & 43 & & & \\
\hline
\end{tabular}

$* p<0.05, * * p<0.01, * * * p<0$.

This table showed the change of ability after class by the PC utilization before class. According the statistical analysis, the change of apparatus utilization ability after class between two groups of PC utilization ability became clear with different one. But the table showed that difference between two groups was not clear on web presentation utilization ability.

The analysis of variance for the information management ability by ability for use of mobile phone was the same as $<$ Table XVI>.

This table showed the change of ability after class by the mobile phone utilization before class. According the statistical analysis, the change of information management ability after class between two groups of mobile phone utilization ability became clear with different one.

\section{CONCLUSION}

\section{A. Summary}

This work focused on the change of ability for prime aged person who should use smart working environment, and it applied by the one of school which teach to the person who want to acquire the ability for computer and mobile phone utilization in smart society. In order to comprehend their smart working ability for prime aged person, this work performed experimental analysis about 44 learners who finished smart worker learning program.

This work introduce the smart worker definition and smart worker learning program. Smart phone education and the computer utilization education for the adult learner are easy to save the computer basics and utilization, the internet basics, documentation skill and qualification subject which are easy to search the lecturer. That subject include the video, and carry out only general computer education. The lecture which can expanded from computer and a smartphone to the cloud utilization. The concept that this study can synchronize can affect the lecture establishment and the business result of the engine including the completion rate of attendance students is the fact evading.

This work break down the smart working ability to 4 factors of cloud, apparatus, document making and information management abilities, and performed 2 time survey for 44 learners before and after class. Using responds of survey, this work analyzed descriptive statistics and also did analysis of variance by the PC and mobile phone utilization ability.

The result of this research showed that change of ability appeared in cloud utilization, apparatus utilization, document making utilization, and information management utilization evidently after smart worker learning program for prime aged persons, and also this work showed that when they have the ability of PC utilization or mobile phone utilization, and they can acquire the 4 factors of ability for smart working.

\section{B. Future Work}

As for the future study direction of this study, ability for computerization got the result that meant the existence that improved after smart worker program completion to a learner for many years at cloud utilization, smart apparatus utilization, documentation utilization and information management utilization on the cloud environment. It is not a smart worker who can use smart apparatuses well simply, 
smart worker of the truth is the person who can utilize tools well, and also can apply it in the real smart work.

This study focus on the result after smart worker education program, so this work could not comprehend about they applied it to their work or not. A continuous study considers it to have to be progressed about influence for a change and the result of the smart working duties method, and improvement of the ability for information utilization gets it after now

\section{REFERENCES}

[1] J.-C. Yoon, S.-H. Han, and M.-S. Park, "Effects of Adults' Participation Motives for Lifelong learning, and their satisfaction and learning outcomes on social capital formation," Journal of the Korea Academia-Industrial cooperation Society, vol. 17, no. 2 pp. 579-589, 2016 ,

[2] Korea Information Society Agency, "A revolutionary change in the way we work 'smart work'," Seoul: Korea Information Society Agency, 2010.

[3] D.-H. Yang, "Cloud services for smart work," Korean Society for Internet Information, vol. 12, no. 3, pp. 52-56, 2011.

[4] S.-B. Gang and S.-Y. Jeong, "Google Apps for Smart working," 2015.

[5] K.-S. Noh, K.-G. Kim, and J.-B. Byun, "A study on the competence model of smart worker," The Journal of Digital Policy \& Management, vol. 9, no. 5, pp. 215-224, 2011.
[6] M. Okada and J.-H. Kim, "Smart worker: Worker in the cloud era," Seoul: New proposal, 2011.

[7] M.-G. Gang, "Survey on lifelong education demand survey of adults," Ministry of Education, 2014.

[8] T.-Y. Kim, "Country without retirement (Double the national economy)," Seoul: Samsung Economic Research Institute, 2013.

[9] S.-S. Hong, "EVERNOTE by professionals," 2015.

[10] W. Ho, "Smart working mind," Kongju National University, 2012.

[11] Wikipedia. [Online]. Available: https://www.wikipedia.org

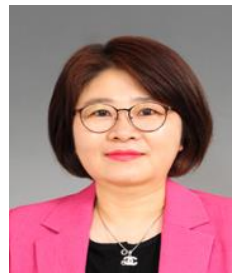

Mariah Park was born on Oct 28, 1963 at Mokpo, Korea. She is a Phd. student at Korea National Open University. She is instructor at National Information Agency. She is interested in digital literacy, distance education and smart working.

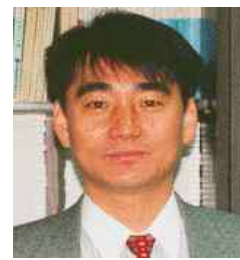

Tea In Han was born on May 19, 1955 at Seoul, Korea. He is Ph.D. at Korea University in 1999. His major is AI of computer science. He is professor of Korea National Open University. He is interested in e-learning, deep learning, distance learning. 